\title{
The Impact of Economic Regulation on Retail Sector: Regulation of Business Hours of Large Discount Stores in South Korea
}

\author{
Kwangho Jung* and Sooki Lee**
}

\begin{abstract}
Recently the large discount retailers (LDRs) including large discount chains (e.g., Emart, Homeplus, and Lotte Mart) and super supermarkets (SSMs) have been at the center of disputes in the retail industries in Korea. The 2012 Distribution Industry Development Act has allowed the head of a city or county to regulate the business hours between large mega-retailers and small and family-run stores in the neighborhood. The regulation of the business hours of the large discount retailers may have heterogeneous effects on their sales depending on various contexts of the market situation. The reduction of the business hours assumes a significant negative effect on the amount of sales of LDRs. However, the degree of reduction may significantly differ from how the LDRs respond to the regulation. The reduction of sales of LDRs is natural if LDRs affected by the regulation do not make any effort to promote sales. On the other hand, if LDRs try to maintain their sales with various marketing strategies and resources, their sales may not decrease and even relatively increase compared to the size of the sales for LDRs that are not affected by the regulation. In addition, although the regulation of the business hours for LDRs can reduce operating hours, their sales may increase due to an increase of market demand in some growing places. For instance, the sales in LDRs located at the market place where new large housings and apartments have been growing may increase. The increasing demand derived from the new population growth can cancel out the decrease of the sales from the regulation of the business hours. Our findings, relying on using DID method before and after the regulation, show three different types of the impact of the regulation change on the sale of LDRs across five regions including decreasing, constant, and increasing patterns.
\end{abstract}

Keywords: Economic regulation, retail sector, large discount retailer, traditional markets, SSMs

* Professor, Korea Institute of Public Affairs, Graduate School of Public Administration, Seoul National University. Email: kwjung77@snu.ac.kr.

** Ph.D. Candidate, Graduate School of Public Administration, Seoul National University. Email: retaliation761@gmail.com.

Manuscript received February 10, 2017; out for review February 17, 2017; review completed March 28, 2017; accepted March 31, 2017.

The Korean Journal of Policy Studies, Vol. 32, No. 1 (2017), pp. 99-124.

(C) 2017 by the GSPA, Seoul National University 


\section{INTRODUCTION}

For the last three decades, policy debates have concerned the sustainability of small and local traditional markets due to a significant expansion of large discount retailers (LDRs) including Walmart, Costco, Kroger, Schwarz, and Tesco1. The local small retail sector has increasingly faced a globally turbulent economy that global giant retail stores generate through promoting competitiveness, discounting and global online shopping and e-commerce. The local retail market has struggled to sustain its ecosystem and government has designed regulation including land-use zoning, building size codes, business hours, and environmental impact assessment against LDRs (e.g., COSTCO, Emart, Homeplus, Lotte Mart) and super supermarkets (SSMs) (e.g., Lotte Super and Homeplus Express) in South Korea.

South Korea has illustrated a rapid expansion of national retail chain stores during the last two decades. Since the first emergence of E-mart in 1993, large discount stores including Home-plus and Lotte Mart have spread in South Korea. For instance, more than $50 \%$ of the counties in South Korea had at least one large discount store; and mega retail stores and SSMs rapidly expanded their market against the local and small retail sector. Despite government efforts to encourage people to shop at traditional markets, recent reports show that their overall sales have sharply declined over the past few years. Thus, the Korean government and law-makers introduced mandatory Sunday store closings in 20122 in order to protect small and family-run stores against big retailers. The new regulation, through the additional amendment of the Retail Industry Development Act, Article 12-2, enabled cities, counties, and districts to regulate the business hours of large or semi-large stores. The new regulation stipulates that local governments can limit not only the business hours but also the business days of the stores. This new regulation for co-existence based on shared growth in the retail industry allowed the heads of basic local autonomous entities - city, county, borough - to coordinate the business hours of LDRs. More specifically, the law can order stores to close between midnight and 8 a.m. and/or to close up to 2 days a month. For

1. The 2016 Global Powers of Retailing research shows the ranking of the retail revenue for global mega stores in the 2014 financial year. The top is Walmart with $\$ 485.6$ billion, the second ranked is Costco Wholesale Corporation with $\$ 112.6$ billion, and, the third ranked is Kroger with $\$ 108.4$ billion. The others include Tesco ( $\$ 99.7$ billion), Carrefour ( $\$ 98.5$ billion), Aldi ( $\$ 86.5$ billion), Metro Group ( $\$ 85.6$ billion), Home Depot ( $\$ 83.2$ billion) and Walgreens (\$76.4 billion). (Website: https:/www.esmmagazine.com/wal-mart-costco-andkroger-named-as-top-global-retailers/23583. Accessed on February 8, 2017).

2. The regulation of business hours for mega stores and SSMs was promulgated on April 10, 2012 and became effective April 22, 2012. 
instance, the new regulation of business hours for the large discount stores requires three major discount stores - Emart, Homeplus and Lotte Mart to reduce their business hours. According to this new regulation, the large discount stores and SSMs close two Sundays per month.

The new regulation involves complex legal debates and battles 3. Local governments introduced the restrictions to protect mom-and-pop stores, but the big three supermarket chains filed a petition with the Seoul Administrative Court citing the new law as infringing on consumers' rights. On November 2015, the Supreme Court of Korea supported the decision to keep large supermarkets closed twice a month, in order to protect small and medium sized businesses. There is, however, an unresolved policy issue concerning whether or not the new regulation of business hours reduces the sales of a large discount store.

While the large discount stores argue their sales significantly decreased due to the business hours restriction, relatively little empirical research has provided scientific evidence about this debate. It is important to identify the impact of the regulation of business hours on the sales of large discount stores and provide solid empirical evidence about what impact the new regulation has on the retail sector. The impact of the regulation on the sales of large discount stores may vary among different market strategies and environments. There are three logical scenarios.

First, the regulation may not decrease the sales of LDRs. Compared to the sales for super discount stores not affected by the regulation (i.e., Control group), the sales for those affected by the regulation (i.e., Treatment group) can increase if the large discount stores of the treated group can make various efforts to obtain more sales and expand into new markets in their business areas. Second, the final sales volume may not be significantly changed due to the effects of two opposing factors. The regulation of business hours can directly reduce sales due to closing two Sundays a month, but big stores can invest in more marketing efforts to attract consumers. Third, the regulation may significantly reduce their sales if the large discount stores do not make any more efforts to increase their sales.

The remainder of the paper is organized as follows. Section II reviews relevant lit-

3. The six stores filed a complaint against the Seongdong District Office and Dongdaemun District Office in November 2012. The High Court on December 12, 2014 reversed the first ruling, saying the government's forced holidays and business hour restrictions were against the law. On November 19, 2015, a Supreme Court ruling ended a three-year battle by big retail chains. The court ruled 11 to 2 in favor of keeping the supermarkets closed twice a month. The Supreme Court dismissed an appeal by big supermarket chains to free them from regulations that force them to close two Sundays a month and limit their operating hours, sending the case back to the Seoul High Court on Thursday. 
erature concerning government intervention in the retail industry, with a summary of key issues of the impact of government regulation on the retail market of LDRs. Section III describes the main data used to evaluate the impact of government regulation of business hours of LDRs. Section IV shows that using DID method, before and after the regulation, there are three different types of impact of the regulation change on the sales of LDRs across five regions including decreasing, constant, and increasing patterns. The final section provides discussion and policy implications.

\section{REVIEW OF RELEVANT LITERATURE}

\section{Debates on the Impact of Regulation of LDRs}

For the last decade, various types of regulations in the retail sector have involved competing views on their positive or negative effects on local economies and the business environment (Basker 2005a; 2005b; Bresnahan and Reiss 1991; Foster et al. 2006; Goos 2005; Skuterud 2005; Wenzel 2011; Wrigley and Lowe 2010; Williamson et al. 2006). Many OECD countries have adopted economic regulations for large stores including big-box mega stores, and SSMs in order to protect business ecosystems of small local retail stores and amenities of community (Ennis 2010; Pilat 1997). There are, however, completely different views on the impact of economic regulations such as entry regulations and business hours on economic performance (e.g., price, shopping convenience, employment, and productivity), and negative externalities (e.g., contamination and congestion). There are pros and cons of regulations against SSMs entering the retail market.

Planning regulations are often used to curb the entry of large out-of-town retail stores - also known as "big-boxes." These policies, which have been widely adopted across OECD countries (Cheshire et al. 2014; Ennis 2008; Pilat 1997), find their justification in the need to prevent the possible negative externalities generated by big-boxes on local communities (e.g. congestion, damages to the environmental décor) and, in particular, to protect the survival of smaller retailers and the amenities they providesuch as personalized and local service-from new sources of competitive pressure. However, entry regulations have been severely criticized for their possible effects on the efficiency of the retail sector. Constraining the entry of big-boxes, it has been argued, could reduce economies of scale, and slow down the introduction of IT innovations complementary with large surfaces (McKinsey Global Institute 1998; Schivardi and Viviano 2011). Furthermore, entry regulations could also hinder the reallocation of resources and employment between and within firms, which appear to be a major 
driver of productivity growth in the retail sector. The literature reviews can be summarized as follows.

Barriers to entry may increase the equilibrium price (Griffith and Harmgart, 2012) and decrease the generation of employment (Griffith and Harmgart, 2012; Bertrand and Kramarz, 2002). Entry may have reduced the equilibrium prices, which helped save $25 \%$ expenditure on food (Hausman and Leibtag, 2007). The dynamic of entry and exit may explain the productivity increase in the U.S. during the 1990's (Foster, Haltiwanger, and Krizan, 2006). Entry of Wal-Mart created 100 new jobs in the first year, but ended up losing 50 jobs in the following year (Basker, 2005a). Further, entry of Wal-Mart had an influence in increasing competition in the service quality and lowering inventory shortfalls to $24 \%$ (Matsa, 2011) and reinforced the competition level and responsibility for $40 \sim 50 \%$ of exits (Jia, 2008). The entry of Wal-Mart had a small but significant effect in lowering the prices in the short term, with a much stronger effect in the long term; the effect was greater in small cities where the competition was low prior to entry of Wal-Mart (Basker, 2005b). In addition, the entry regulation may involve potential side effects in the retail industry. For instance, Sadun (2015) analyzed a planning reform launched in the United Kingdom in the 1990s and showed that independent retailers were actually harmed by the creation of entry barriers against large stores. Instead of simply reducing the number of new large stores entering a market, the entry barriers created the incentive for large retail chains to invest in smaller and more centrally located formats, which competed more directly with independents and accelerated their decline. Overall, these findings suggest that restricting the entry of large stores does not necessarily lead to a world with fewer stores, but one with different stores, with uncertain competitive effects on independent retailers.

Numerous studies have addressed the impact of the regulation of entry in the retail trade sector on price of products and employment. However, little empirical research has explored the regulation of opening days on sales of LDRs with the actual revenue data derived from mega stores and SSMs. In spite of the wide interest generated by this debate, relatively little empirical evidence exists on the actual cost and benefits associated with planning regulations. In particular, the idea that restricting the entry of large retail stores can effectively change the nature of retail competition in favor of independent stores has received limited empirical investigation. This is primarily dictated by the institutional nature of planning policies, which tend to show very little variation within countries and over time, and are thus often indistinguishable from other country characteristics. 


\section{RESEARCH METHOD, MODEL SPECIFICATION AND DATA}

\section{Various Effects of the Regulation of the Business Hours of LDRs}

Since the early 2000s, with steadily declining traditional local retail markets, mega stores and SSMs have been at the center of policy disputes in the retail industries in Korea. In order to protect local traditional markets and mom \& pop stores, the Korean National Assembly introduced the new Distribution Industry Development Act of $2012^{4}$ to restrict the business hours of large retailers such as E-Mart, Homeplus, Lotte Mart and Costco. The regulation of the business hours of LDRs may have heterogeneous effects on their sales depending on various contexts of market situations. Put simply, the reduction of the business hours may have a significant negative impact of the sales of LDRs. However, the degree of reduction may significantly differ depending on how LDRs respond to the regulation. The reduction of sales of LDRs is natural if LDRs affected by the regulation do not make any effort to promote sales. However, if LDRs try to maintain their sales with various marketing strategies and resources, their sales may not decrease and may even increase relative to the size of sales of LDRs who make no efforts to maintain their sales. In addition, although the regulation of business hours for LDRs can reduce operating hours, their sales may increase due to an increase in market demand. For instance, sales may increase in LDRs located at the [a] market place where new housing is being built. The increasing demand derived from the new population growth can cancel out the decrease in sales from the regulation of business hours.

4. 'The Development Law of Distribution Industry' was revised for the protection of traditional local markets. For instance, since November 24, 2010, new entrance of big-box stores within the 500-meter range from traditional market preservation areas has become illegal and in June 2011, the preservation ranges of traditional markets extended to a one-kilometer area. This regulation came into force on January 17, 2012. The new regulation restricted business hours from midnight to 8 A.M., as well as obliged big-box stores to close once or twice a month. A year later, the regulation on the big-box stores strengthened; they should be closed from midnight to 10 A.M., and have days off twice a month on Sunday (Jung, 2015). This regulation was designed to restrict the business activities of large discount stores to help struggling traditional markets and small mom-and-pop stores. The act, nicknamed the Sunday Shopping Regulation offered a legal basis of mandatory days off at big-box stores (Lee, 2015). 


\section{A Simple Regression with a Dummy Variable Representing Before and After}

Based on a simple econometric model, we can develop these different scenarios concerning the impact of the regulation of the business hours for large discount chains and LDRs in South Korea. The following simple regression model shows the effect of regulation as the size of $\beta_{1}$.

$$
\mathrm{SALE}_{i t}=\boldsymbol{\beta}_{0}+\boldsymbol{\beta}_{1} \mathrm{After}_{-} \mathbf{R g}_{i t}+\varepsilon_{i t}
$$

where SALE it $_{\text {r }}$ represents the amount of sales of 15 LDRs $i$ at period $t$ with 154 weeks, After_Rg represents a dummy variable taking a value of one for the time period after regulation of the business hours for LDRs and zero for the period before the regulation,

$\beta_{0}$ is an intercept term, the value of $\beta_{1}$ represents the impact of the regulation, and $\varepsilon$ represents an error term.

The OLS (Ordinary Least Square) estimate of $\beta_{1}$ is the difference in the average sales between after $\left(\operatorname{SALE}_{1}=\beta_{0}+\beta_{1}\right)$ and before $\left(\operatorname{SALE}_{0}=\beta_{0}\right)$ the regulation change. However, this model cannot distinguish the regulation policy effect from a secular change such as a decrease in sales over time due to an economic decline. With 2 periods only between before and after the regulation change, distinguishing this is almost impossible. The estimate of $\beta_{1}$ is unbiased only under the very strong assumption that, absent the regulation impact, there would have been no change in average sales for LDRs.

\section{Difference-in-Differences (DID) Method}

With control group data unaffected by the regulation, it is possible to develop a more convincing estimation methodology. A way to avoid the potential bias derived from the simple difference method is to compare outcomes before and after a regulation change for a group affected by the change ( $\mathrm{T}=$ Treatment Group, if Treat $\mathrm{Rg}=1$ ) to a group not affected by the change $(\mathrm{C}=\mathrm{Control}$ Group, if Treat $\mathrm{Rg}=0))$. The idea is to correct the simple difference before and after for the treatment group by subtracting the simple difference for the control group. In this framework of data distribution between treatment and control groups, the estimate of DID can be derived from the following:

$$
\mathrm{DID}=\left[\operatorname{Exp}\left(\mathrm{SALE}_{1} \mid \mathrm{T}\right)-\operatorname{Exp}\left(\mathrm{SALE}_{0} \mid \mathrm{T}\right)\right]-\left[\operatorname{Exp}\left(\mathrm{SALE}_{1} \mid \mathrm{C}\right)-\operatorname{Exp}\left(\mathrm{SALE}_{0} \mid \mathrm{C}\right)\right]
$$


Figure 1. Different Types of Regulation Effects of Business Hours on Sale of LDRs

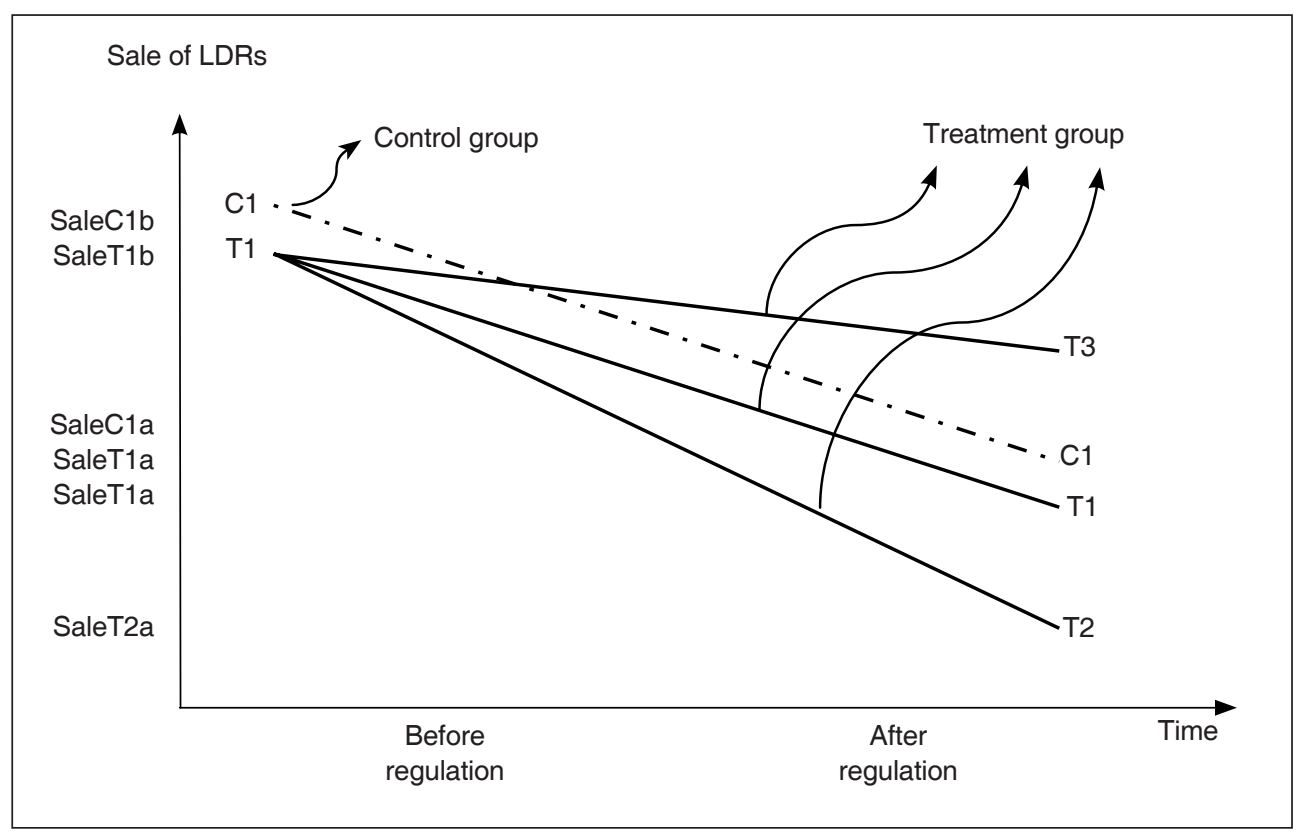

As Figure 1 shows, a new regulation to reduce the business hours of mega stores and SSMs may have various types of effects on sales. The sales after the regulation may illustrate three types of characteristics depending on not only market demand but also the large discount stores' response to the regulation. First, the new regulation can reduce the amount of the sales of LDRs due to closing two Sundays every month. The reduction representing [T1-T2] is larger than that of [C1-C2]. The regulation has a direct impact on reducing the sales of the large discount stores through shrinking their operation hours. Second, however, large discount stores can respond to the regulation and promote their sales through various marketing strategies. The impact of the regulation has no impact on sales after controlling the decreasing trend of market size due to an overall economic decline. That is, the reduction of [T1-T1] between before and after the regulation is almost the same as that of [C1-C1] representing the sales of LDRs in the control group. In this situation, while closing on two Sundays reduces the revenue of the large discount stores, some factors including various marketing efforts can promote sales. Third, although the sales of LDRs decrease after the new regulation due to overall declining economic trends, the reduction of [T1-T3] is less than that of [C1-C2]. That is, after the regulation, the sales of LDRs of the treatment group increase compared to those of the control group. Some regions provide a significant 
increase in demand for the sales of the large discount store, which may increase sales even after the adoption of the regulation.

We introduce treatment and control groups across five regions with different characteristics for each treatment and control group. The large discount stores of the treatment groups in some regions have a strong tendency to promote sales through various marketing strategies but not [those?] in other regions. The large discount stores of the control groups in some regions have the same closing days as those of the treatment groups. This means the treatment effect of the new regulation is the same for both control and treatment groups. In addition, treatment groups in some regions face a relatively positive economic environment with a growing market power compared to control group. Table 1 displays all treatment and control groups across five regions with these heterogeneous characteristics.

Table 1. Treatment and Control Groups of the Regulation Change

\begin{tabular}{|c|c|c|}
\hline Region & Treatment Group & Control Group \\
\hline $\begin{array}{l}\text { Region 1: } \\
\text { Seoul } \\
\text { (Metropolitan) }\end{array}$ & $\begin{array}{l}\text { - Emart (Mok-Dong Branch) } \\
\text { - Emart (Sinwol- Dong Branch) } \\
\text { - Emart (Yongsan-Gu Branch) }\end{array}$ & - Emart (Yongsan Branch) \\
\hline $\begin{array}{l}\text { Region 2: } \\
\text { Gyeonggi-Do } \\
\text { (Province) }\end{array}$ & - Emart (Icheon City Branch) & - Emart (Anseong City Branch) \\
\hline $\begin{array}{l}\text { Region 3: } \\
\text { Gyeonggi-Do } \\
\text { (Province) }\end{array}$ & - Emart (Hanam City Branch) & $\begin{array}{l}\text { - Emart (Namyangju City- } \\
\text { Namyangju Branch) } \\
\text { - Emart (Namyangju City- } \\
\text { Donong Branch) } \\
\text { - Emart (Namyangju City- } \\
\text { Jinjoep Branch) }\end{array}$ \\
\hline $\begin{array}{l}\text { Region 4: } \\
\text { Gyeongsangbuk-Do } \\
\text { (Province) }\end{array}$ & - Emart (Andong City) & - Emart (Sangju City) \\
\hline $\begin{array}{l}\text { Region 5: } \\
\text { Ulsan } \\
\text { (Metropolitan) }\end{array}$ & $\begin{array}{l}\text { - Lotte-Mart (Ulsan Buk-Gu, } \\
\text { Jinjang Branch) }\end{array}$ & $\begin{array}{l}\text { - Lotte-Mart (Ulsan, Nam-Gu } \\
\text { Branch) } \\
\text { - Emart (Ulsan, Nam-Gu Branch) } \\
\text { - Emart (Ulsans, Jung-Gu, } \\
\text { Haksung Branch) }\end{array}$ \\
\hline
\end{tabular}

Note: The closing days of business hours are the same between treatment and control group in Region 3. 
The DID estimate is an unbiased estimate of the effect of the regulation change if, absent the regulation change, the average change in $\mathrm{SALE}_{1}-\mathrm{SALE}_{0}$ would have been the same for treatment and controls. This is the 'parallel trend' assumption.

$$
\begin{gathered}
\mathrm{SALE}_{i t}=\beta_{10}+\beta_{11} \text { After_Rg }_{i t}+\beta_{12} \text { Treat_Rg } \operatorname{Rg}_{i t}+\beta_{13} \text { Policy_Rg } \\
\text { where Policy_Rg }(=\text { After_Rg } * \text { Treat_Rg })
\end{gathered}
$$

DID estimates are more reliable when you compare policy outcomes just before and just after the policy change because the identifying assumption (parallel trends) is more likely to hold over a short time-window. However, with a long time trend, many other things are likely to happen and confound the regulation change effect. It is often more interesting to know the medium or long term effect of a policy change.

Fixed effects can be seen as a generalization of DID in the case of more than two week periods (e.g., 100 week periods) and more than 2 groups (e.g., 15 SSM groups). Suppose that $\mathrm{LDRs}_{i}$ in year $\mathrm{t}$ experience the policy change from regulation business hours of LDRs [meaning unclear - is the regulation applied in year t when it wasn't before?]. We can introduce the following regression model to identify the effect of Policy_Rg on an outcome SALE as follows. The model of EQ3 is a pooled OLS regression with time and group dummies.

$$
\text { SALE }_{i t}=\beta_{20}+\beta_{21} \text { After_Rg } i t+\beta_{22} \text { TREAT_Rg }{ }_{i t}+\beta_{23} \text { Policy_Rg }{ }_{i t}+\alpha_{\mathrm{i}}+\theta_{\mathrm{t}}+\xi 2_{i t} \cdots \text { (EQ2) }
$$

\section{Panel Regression with DID Method}

With no fixed effects, the estimate of $\beta_{23}$ is biased if treatment Policy_ $\mathrm{Rg}_{\text {it }}$ is correlated with $\xi_{i t}$ (that is, correlated with the outcome SALEit), even if the treatments of Policy_ $\operatorname{Rg}_{\text {it }}$ were all identical across time and groups. To avoid this problem, we can introduce a panel regression model with time dummies and group dummies to consider fixed effects as EQ4 shows.

$$
\mathrm{SALE}_{i t}=\beta_{30}+\beta_{31} \text { After_Rg }{ }_{i t}+\beta_{32} \text { Treat_Rg }_{i t}+\beta_{33} \text { Policy_Rg } \operatorname{Rg}_{i t}+\alpha_{\mathrm{i}}+\theta_{\mathrm{t}}+\mathrm{U} 1_{\mathrm{it}} \cdots \cdots . . \text { (EQ3) }
$$

Fixed effects are valid only if the response is immediate. If full responses take more than 1 period, the fixed effects estimate might be biased because the true model

5. The model of EQ1 can be represented as follows:

SALE $_{i t}=\beta_{10}+\beta_{11} * 1($ After_Rg $=1)+\beta_{12} * 1(i \in$ Treat_Rg $)+\beta_{13} * 1($ After_Rg $=1) * 1(i \in$ Treat_Rg $)$ $+\xi 1_{i t}$ 
should include lagged variables Sale $_{\text {it- } 1}$. We can add lagged dependent variables to solve this problem. The regression model of EQ4 provides the lagged effect of the regulation of the business hours as the size of $\eta$.

$$
\begin{aligned}
& \mathrm{SALE}_{i t}=\beta_{40}+\eta \mathrm{SALE}_{i t-1}+\beta_{41} \text { After_Rg } \mathrm{Rg}_{i t}+\beta_{42} \text { Treat_Rg }_{i t}+\beta_{43} \text { Policy_Rg }_{i t}+\alpha_{i}+ \\
& \theta_{t}+\mathrm{U} 2_{i t}
\end{aligned}
$$

\section{Data Characteristics}

We use panel data with 16 cross-sectional units of large discount stores with 14 Emarts and 2 Lotte Marts and from 152 to 154 week periods. The total sample size is 2,036. Only two mega stores of Lotte Mart in Ulsan metropolitan city have 152 week periods due to their calculation process of sales data. All the other large discount stores do 154 week periods. The data of sales during these periods are provided from Emart and Lotte Mart. Previous studies (Cho 2014; Cho et al. 2015; Choi and Jeong 2016; Jung and Kim 2015; Kim 2016) have not used the real sales data of the large discount chains. Previous empirical findings about the impact of the regulation of the business hours on the size of sales of the mega stores may have problems due to measurement errors. However, this study uses the real sales data and estimates the impact of the regulation on the reduction of sales.

\begin{tabular}{|c|c|c|c|c|c|c|c|c|c|c|}
\hline \multirow{2}{*}{$\begin{array}{c}\text { Region } \\
\text { (Metropolitan } \\
\text { or } \\
\text { Providence) }\end{array}$} & \multirow{2}{*}{ ID-LDRs } & \multicolumn{3}{|c|}{$\begin{array}{c}\text { Whole } \\
(\mathrm{N}=2,306)\end{array}$} & \multicolumn{3}{|c|}{$\begin{array}{c}\text { Before } \\
(\mathrm{N}=1,089)\end{array}$} & \multicolumn{3}{|c|}{$\begin{array}{l}\text { After } \\
(2,317)\end{array}$} \\
\hline & & Mean & SD & $\mathrm{N}$ & Mean & SD & $\mathrm{N}$ & Mean & SD & $\mathrm{N}$ \\
\hline \multirow{3}{*}{ (1) } & $\begin{array}{c}\text { 14-Emart } \\
\text { (Mok-Dong) }\end{array}$ & 21.564 & 0.251 & 154 & 21.593 & 0.239 & 73 & 21.538 & 0.259 & 81 \\
\hline & $\begin{array}{c}\text { 15-Emart } \\
\text { (Sinwol-Dong) }\end{array}$ & 19.993 & 0.268 & 154 & 20.014 & 0.283 & 73 & 19.974 & 0.254 & 81 \\
\hline & $\begin{array}{c}\text { 16-Emart } \\
\text { (Yongsan-Gu) }\end{array}$ & 21.842 & 0.259 & 154 & 21.865 & 0.248 & 73 & 21.821 & 0.269 & 81 \\
\hline \multirow{2}{*}{ (2) } & $\begin{array}{c}\text { 3-Emart } \\
\text { (Anseong City) }\end{array}$ & 20.803 & 0.260 & 154 & 20.814 & 0.241 & 77 & 20.792 & 0.279 & 77 \\
\hline & $\begin{array}{c}\text { 4-Emart } \\
\text { (Icheon City) }\end{array}$ & 21.437 & 0.249 & 154 & 21.470 & 0.249 & 77 & 21.405 & 0.247 & 77 \\
\hline (3) & \begin{tabular}{|c|} 
8-Emart \\
(Namyangju City, \\
Namyangju)
\end{tabular} & 21.593 & 0.256 & 154 & 21.618 & 0.239 & 78 & 21.567 & 0.271 & 76 \\
\hline
\end{tabular}

Table 2. Descriptive Statistics Before and After Regulation 


\begin{tabular}{|c|c|c|c|c|c|c|c|c|c|c|}
\hline & $\begin{array}{c}\text { 9-Emart } \\
\text { (Namyangju City, } \\
\text { Donong) }\end{array}$ & 21.022 & 0.257 & 154 & 21.061 & 0.241 & 78 & 20.982 & 0.268 & 76 \\
\hline & $\begin{array}{c}\text { 10-Emart } \\
\text { (Namyangju City, } \\
\text { Jinjoep) }\end{array}$ & 20.689 & 0.262 & 154 & 20.714 & 0.232 & 78 & 20.663 & 0.289 & 76 \\
\hline & $\begin{array}{c}\text { 11-Emart } \\
\text { (Hanam City) }\end{array}$ & 21.228 & 0.267 & 154 & 21.238 & 0.231 & 78 & 21.219 & 0.301 & 76 \\
\hline \multirow{2}{*}{ (4) } & $\begin{array}{c}\text { 5-Emart } \\
\text { (Sangju City) }\end{array}$ & 20.092 & 0.304 & 154 & 20.124 & 0.288 & 68 & 20.067 & 0.315 & 86 \\
\hline & $\begin{array}{c}\text { 6-Emart } \\
\text { (Andong City) }\end{array}$ & 20.828 & 0.307 & 154 & 21.001 & 0.248 & 68 & 20.691 & 0.279 & 86 \\
\hline \multirow{4}{*}{ (5) } & $\begin{array}{c}\text { 2-Lotte-Mart } \\
\text { (Ulsan Buk-Gu, } \\
\text { Jinjang) }\end{array}$ & 21.139 & 0.186 & 152 & 21.158 & 0.185 & 67 & 21.124 & 0.186 & 85 \\
\hline & $\begin{array}{c}\text { 1-Lotte-Mart } \\
\text { (Ulsan Nam-Gu) }\end{array}$ & 21.482 & 0.160 & 152 & 21.522 & 0.162 & 67 & 21.451 & 0.150 & 85 \\
\hline & $\begin{array}{c}\text { 12-Emart } \\
\text { (Ulsan Nam-Gu) }\end{array}$ & 21.319 & 0.263 & 154 & 21.345 & 0.242 & 67 & 21.299 & 0.278 & 87 \\
\hline & $\begin{array}{c}\text { 13-Emart(Ulsan } \\
\text { Jung-Gu, } \\
\text { Haksung) }\end{array}$ & 19.551 & 0.295 & 154 & 19.694 & 0.265 & 67 & 19.441 & 0.269 & 87 \\
\hline
\end{tabular}

Notes: $\mathrm{SD}=$ Standard deviation. $\mathrm{N}=$ Sample size. The amount of sales of LDRs is transformed by natural logarithm.

\section{EMPIRICAL RESULTS}

\section{Comparative Analysis between Treatment and Control Groups Before and After the New Regulation of Business Hours}

The simple comparative analysis between treatment and control groups provides a brief picture of the overall trend of the difference in sales before and after the new regulation. As Table 3 shows, there is almost the same trend of the sales between two groups before and after the regulation in the case of Region 1. This implies that the new regulation may have little impact on the sales of the large discount stores, if LDRs can create an effective sales and marketing strategy against Sunday closings. However, the regulation may have diverse effects on the size of the sales, depending on market ecosystem from supply side or demand side in retail sector of South Korea. For instance, the regulation may have a positive or negative impact on the 
sales for some regions. In the case of Region 2 and Region 4, the sales of treatment groups show a relative decrease compared to those of control groups. This suggests that the regulation may have a direct negative impact on the sales of the large discount stores in Region 2 and Region 4. On the contrary, in the case of Region 3 and Region 5, the sales of treatment groups show a relatively smaller decrease compared to that of control groups. This suggests that the regulation can even increase the sales of the large discount stores in Region 3 and Region 5 with new growing commercial areas. More rigid analysis is required to confirm these trends derived from Table 3.

Table 3. Simple Mean Differences between Before and After the New Regulation of Operation Hours

\begin{tabular}{|c|c|c|c|c|}
\hline Region & $\begin{array}{c}\text { ID of LDR } \\
\text { (Treatment vs. Control) }\end{array}$ & Before (B) & After (A) & $\begin{array}{c}{[(\mathrm{A}-\mathrm{B}) / \mathrm{B}] *} \\
100\end{array}$ \\
\hline \multirow{3}{*}{ Region 1} & 16 (Control-Treatment) & 3,210 & 3,075 & $-4.21 \%$ \\
\hline & 14 (Treatment) & 2,438 & 2,320 & $-4.84 \%$ \\
\hline & 15 (Treatment) & 507 & 485 & $-4.34 \%$ \\
\hline \multirow{2}{*}{ Region 2} & 3 (Control) & 1,121 & 1,102 & $-1.69 \%$ \\
\hline & 4 (Treatment) & 2,164 & 2,025 & $-6.42 \%$ \\
\hline \multirow{4}{*}{ Region 3} & 8 (Control) & 2,501 & 2,386 & $-4.60 \%$ \\
\hline & 9 (Control) & 1,433 & 1,328 & $-7.33 \%$ \\
\hline & 10 (Control) & 1,015 & 972 & $-4.24 \%$ \\
\hline & 11 (Treatment) & 1,710 & 1,694 & $-0.94 \%$ \\
\hline \multirow{2}{*}{ Region 4} & 5 (Control) & 571 & 540 & $-5.43 \%$ \\
\hline & 6 (Treatment) & 1,354 & 998 & $-26.29 \%$ \\
\hline \multirow{4}{*}{ Region 5} & 1 (Control) & 2,257 & 2,096 & $-7.13 \%$ \\
\hline & 12 (Control) & 1,909 & 1,831 & $-4.09 \%$ \\
\hline & 13 (Control) & 368 & 285 & $-22.55 \%$ \\
\hline & 2 (Treatment) & 1,574 & 1,519 & $-3.49 \%$ \\
\hline \multicolumn{2}{|l|}{ Total } & 1,618 & 1,500 & -7.29 \\
\hline \multicolumn{2}{|c|}{ Control group of LDRs } & 1,607 & 1,379 & $-14.19 \%$ \\
\hline \multicolumn{2}{|c|}{ Treatment group of LDRs } & 1,634 & 1,651 & $1.04 \%$ \\
\hline
\end{tabular}

Note: Currency unit of sale of LDRs is one million Korean Won. 


\section{A Pooled OLS DID Estimates}

The DID estimates of EQ1 based on a pooled OLS regression show that the regulation of the business hours of LDRs has little effect on their sales except for the case of LDRs in Region 4 (Sangju and Andong cities of Kyoungsangbukdo province). The impact of the regulation in Region 4 significantly reduces the sales of LDRs (p-value is below 0.0001). Based on the DID estimation, the regulation of the business hours reduces, on average, about 30 million [Korean Won] of weekly sales for the Andong

Table 4. OLS Results of Difference-in-Differences Estimation (EQ1)

\begin{tabular}{|c|c|c|c|c|c|c|}
\hline & Variables & Coefficient & SE & $\mathrm{T}$ & $P>|t|$ & \\
\hline \multirow{4}{*}{$\begin{array}{l}\text { Whole } \\
\text { Group }\end{array}$} & Intercept & $20.28^{\star \star *}$ & 0.090 & 224.95 & $<0.0001$ & \multirow{4}{*}{$\begin{array}{l}\mathrm{N}=2,306 \\
\mathrm{~F}(3,2302)=2.79^{\star *} \\
\text { Adj R-squared }=0.0023\end{array}$} \\
\hline & Treat & $-0.254^{*}$ & 0.142 & -1.79 & 0.074 & \\
\hline & After & $-0.338^{* * *}$ & 0.126 & -2.67 & 0.008 & \\
\hline & Policy_effect & 0.299 & 0.195 & 1.54 & 0.125 & \\
\hline \multirow{4}{*}{ Region 1} & Intercept & $21.86^{\star \star *}$ & 0.089 & 245.68 & $<0.0001$ & \multirow{4}{*}{$\begin{array}{l}N=462 \\
F(3,458)=41.61^{* * *} \\
\text { Adj R-squared }=0.2090\end{array}$} \\
\hline & Treat & $-1.062^{\star \star \star}$ & 0.109 & -9.74 & $<0.0001$ & \\
\hline & After & 0.029 & 0.176 & 0.16 & 0.870 & \\
\hline & Policy_effect & 0.189 & 0.194 & 0.98 & 0.330 & \\
\hline \multirow{4}{*}{ Region 2} & Intercept & $20.81^{\star \star \star}$ & 0.029 & 718.55 & $<0.0001$ & \multirow{4}{*}{$\begin{array}{l}N=308 \\
F(3,304)=160.69^{* * *} \\
\text { Adj R-squared }=0.6094\end{array}$} \\
\hline & Treat & $0.656^{\star \star \star}$ & 0.041 & 16.00 & $<0.0001$ & \\
\hline & After & 0.022 & 0.041 & -0.53 & 0.598 & \\
\hline & Policy_effect & -0.043 & 0.058 & -0.74 & 0.461 & \\
\hline \multirow{4}{*}{ Region 3} & Intercept & $21.13^{\star * *}$ & 0.027 & 778.52 & $<0.0001$ & \multirow{4}{*}{$\begin{array}{l}N=616 \\
F(3,616)=4.45^{\star \star} \\
\text { Adj R-squared }=0.0166\end{array}$} \\
\hline & Treat & $0.106^{*}$ & 0.054 & 1.96 & 0.051 & \\
\hline & After & -0.061 & 0.039 & -1.57 & 0.117 & \\
\hline & Policy_effect & 0.042 & 0.077 & 0.55 & 0.585 & \\
\hline \multirow{4}{*}{ Region 4} & Intercept & $20.12^{\star \star *}$ & 0.035 & 581.51 & $<0.0001$ & \multirow{4}{*}{$\begin{array}{l}N=308 \\
F(3,304)=185.96 * \\
\text { Adj R-squared }= \\
0.6438\end{array}$} \\
\hline & Treat & $0.877^{\star \star \star}$ & 0.049 & 17.92 & $<0.0001$ & \\
\hline & After & -0.057 & 0.046 & -1.22 & 0.222 & \\
\hline & Policy_effect & $-0.254^{\star \star *}$ & 0.065 & -3.87 & 0.0001 & \\
\hline \multirow{4}{*}{ Region 5} & Intercept & $18.55^{\text {***}}$ & 0.176 & 105.65 & $<0.0001$ & \multirow{4}{*}{$\begin{array}{l}\mathrm{N}=612 \\
\mathrm{~F}(3,608)=111.97^{\star \star \star} \\
\text { Adj R-squared }=0.3527\end{array}$} \\
\hline & Treat & $-4.301^{* * *}$ & 0.351 & -12.25 & $<0.0001$ & \\
\hline & After & -0.093 & 0.234 & -0.40 & 0.690 & \\
\hline & Policy_effect & 0.059 & 0.469 & 0.13 & 0.899 & \\
\hline
\end{tabular}

Notes: 1) $\mathrm{N}=$ Sample size. 2) Adj.R-squared: Adjusted R-Square. 3) SE = Standard error. 4) ${ }^{* * *, * *}$ and, ${ }^{*}$ indicate statistical significance at the $1 \%, 5 \%$, and $10 \%$ levels, respectively (two-tailed t-test). 
Emart between before and after the regulation. ${ }^{6}$ In addition, simple OLS results based on DID estimates are provided in Appendix 2-1 to 2-6.

However, the pooled OLS estimation may involve various types of potential biases for the impact of the regulation due to omitted fixed effects across different 15 LDRs and over more than 150 week periods as well as potential serial correlations among error terms of the OLS model. Without controlling for these confounding sources, the

Table 5. Diagnosis of Model Appropriateness

\begin{tabular}{|c|c|c|c|c|}
\hline & $\begin{array}{l}\text { Testing 'time' } \\
\text { fixed effects }\end{array}$ & $\begin{array}{c}\text { Breusch-Pagan } \\
\text { LM test of } \\
\text { independence }\end{array}$ & $\begin{array}{c}\text { Modified Wald } \\
\text { test for groupwise } \\
\text { heteroscedasticity }\end{array}$ & $\begin{array}{l}\text { Wooldridge test } \\
\text { for autocorrelation }\end{array}$ \\
\hline $\begin{array}{l}\text { Whole }(N=2,306) \\
-i d=15 \\
\text { - time }=152 \sim 154\end{array}$ & $\begin{array}{l}F(153,2135) \\
=33.89^{\star * \star}\end{array}$ & $\begin{array}{l}x^{2}(105)=110.27 \\
(p \text {-value: } 0.343)\end{array}$ & $\begin{array}{c}x^{2}(15)=595.35 \\
(p \text {-value }<0.0001)\end{array}$ & $\begin{array}{l}\mathrm{F}(1,14)= \\
79.48^{\star * *}\end{array}$ \\
\hline $\begin{array}{l}\text { Region } 1(\mathrm{~N}=462) \\
-\mathrm{id}=3 \\
\text { - time }=154\end{array}$ & $\begin{array}{l}F(152,304) \\
=6.55^{\star \star *}\end{array}$ & $\begin{array}{c}x^{2}(3)=1.66 \\
(p-\text { value: } 0.646)\end{array}$ & $\begin{array}{c}x^{2}(3)=6.61 \\
(p-\text { value }=0.085)\end{array}$ & $\begin{array}{c}F(1,2)= \\
5.84\end{array}$ \\
\hline $\begin{array}{l}\text { Region } 2(\mathrm{~N}=308) \\
-\mathrm{id}=2 \\
\text { - time }=154\end{array}$ & $\begin{array}{l}\mathrm{F}(152,152) \\
\quad=3.17^{\star * \star}\end{array}$ & $\begin{array}{c}x^{2}(1)=0.02 \\
\text { (p-value: } 0.882)\end{array}$ & $\begin{array}{c}x^{2}(2)=0 \\
(p-\text { value }=1.00)\end{array}$ & $\begin{array}{c}F(1,1)= \\
35.99\end{array}$ \\
\hline $\begin{array}{l}\text { Region } 3(N=616) \\
-i d=4 \\
\text { - time }=154\end{array}$ & $\begin{array}{l}F(152,458) \\
=92.16^{* * *}\end{array}$ & $\begin{array}{c}x^{2}(6)=2.70 \\
(p-\text { value: } 0.845)\end{array}$ & $\begin{array}{c}x^{2}(4)=34.18 \\
(p \text {-value }<0.0001)\end{array}$ & $\begin{array}{c}F(1,3)= \\
786.96^{\star \star \star}\end{array}$ \\
\hline $\begin{array}{l}\text { Region } 4(\mathrm{~N}=308) \\
-\mathrm{id}=2 \\
\text { - time }=154\end{array}$ & $\begin{array}{l}\mathrm{F}(152,152) \\
=24.17^{\star * *}\end{array}$ & $\begin{array}{c}x^{2}(1)=1.27 \\
(p-\text { value: } 0.260)\end{array}$ & $\begin{array}{c}x^{2}(2)=0 \\
(p-\text { value }=1.00)\end{array}$ & $\begin{array}{l}F(1,1)= \\
221.14^{\star \star}\end{array}$ \\
\hline $\begin{array}{l}\text { Region } 5(\mathrm{~N}=612) \\
-\mathrm{id}=4 \\
\text { - time }=152 \sim 154\end{array}$ & $\begin{array}{l}\mathrm{F}(152,454) \\
\quad=4.49^{\star \star *}\end{array}$ & $\begin{array}{c}x^{2}(6)=6.49 \\
(p-\text { value: } 0.371)\end{array}$ & $\begin{array}{c}x^{2}(4)=1.14 \\
(p-\text { value }=0.888)\end{array}$ & $\begin{array}{c}F(1,3)= \\
11.86^{\star \star}\end{array}$ \\
\hline
\end{tabular}

Notes: 1) 'time' means the unit of week. 2) ${ }^{* * *, * *}$ and, ${ }^{*}$ indicate statistical significance at the $1 \%, 5 \%$, and $10 \%$ levels, respectively.

6. The simple difference of average sale with natural logarithmic unit for Andong Emart between after and before the regulation is $-0.310[=(20.691)-(21.001)]$, representing $-351,886,058$ $[(968,249,151)-(1,320,135,210)=-351,886,058]$. 
estimates of the pooled OLS would be biased. Table 5 shows what kind of biased sources involve the estimation process derived from the OLS method. First, all models across five different regions show that there are significant time fixed effects, implying the necessity to control the fixed effects. A Wooldrige test also shows that there are significant auto-correlations in Region 3, Region 4, and Region 5, except Region 1 and Region 2. These diagnoses suggest we should consider time dummy variables with fixed effects and lagged variables. Second, we also tested whether or not residuals across entities are correlated due to a long time series in our panel data. The Breusch-Pagan LM test shows no statistical cross-sectional dependence across LDRs [along with different five] [across the five] regions. Third, we test whether or not there is homoscedasticity (or constant variance) in fixed effects. We only found heteroscedasticity in Region 3 and then drew on robust standard errors.

\section{Fixed Effects of Panel Data with DID Frame}

We used a pooled OLS regression with a design of DID. However, these OLS estimates do not control for potential sources of biases derived from SSM specific fixed effects, time fixed effects, and lagged effects. Still keeping the DID design with comparing control and treatment groups between before and after the regulation change, we introduced two way fixed effects, including LDR specific unique characteristics and time specific economic impacts over 154 week periods. Based on the two way fixed effects model on Table 6, we found three different types of the regulation impact on sales of LDRs. The regulation of business hours for LDRs has little impact on Region 1 and Region 2. However, the regulation has significant opposite impacts on the sale of LDRs in the other regions. The regulation even increases the sales of LDRs in Region 3 and Region 5, while the regulation reduces the sales of LDRs in Region 4 (see Table 6). These three different types of effects of the regulation are still robust, even controlling for the lagged effects (see Table 7).

These different outcomes from the new regulation are related to the differences in both treatment and control groups across the five regions. As Table 1 shows, there are five different regions with both treatment and control groups. The DID estimate from Region 1 representing the impact of the regulation has the large discount stores as treatment group to promote their sales against the closing regulation of business hours; this may lead to a reduction of the impact of the regulation or no impact at all of the regulation on their sales. Despite the reduction of business hours, the large discount stores of the treatment group in Region 1 tend to make more efforts to promote their sales. The positive impact of the new regulation on sales for large discount stores in Region 5 has a flourishing business area to boost their sales and surpass the negative 
Table 6. Panel DID Results from EQ 3 (Two Way Fixed Effects Model)

\begin{tabular}{|c|c|c|c|c|c|c|}
\hline & & Coefficient & SE & t-value & $P>|t|$ & \\
\hline \multirow{4}{*}{ Whole } & Intercept & $19.469^{\star \star \star}$ & 0.038 & 506.67 & $<0.0001$ & R-square: within $=0.715$ \\
\hline & Treat & 0.028 & 0.026 & 1.07 & 0.283 & $\begin{array}{r}\text { between }=0.041 \\
\operatorname{Corr}\left(\mathrm{u}_{\mathrm{i}}, \mathrm{Xb}\right)=-0.011\end{array}$ \\
\hline & After & -0.036 & .024 & -1.50 & 0.134 & rho $=.996$ \\
\hline & Policy_effect & -0.011 & .012 & -0.88 & 0.377 & $\begin{array}{r}\sigma_{\mathrm{u}}=2.38, \sigma_{\mathrm{e}}=0.14 \\
\mathrm{~F}(156,2135)=34.38^{\star \star \star}\end{array}$ \\
\hline \multirow{4}{*}{ Region 1} & Intercept & $20.277^{\star \star *}$ & 0.091 & 222.71 & $<.0001$ & R-square: within $=0.769$ \\
\hline & Treat & 0.003 & 0.033 & 0.09 & 0.930 & $\begin{array}{r}\text { between }=0.379 \\
\operatorname{Corr}\left(\mathrm{u}_{\mathrm{i}}, \mathrm{Xb}\right)=-0.002\end{array}$ \\
\hline & After & $0.876^{\star \star \star}$ & 0.128 & 6.84 & $<0.0001$ & rho $=.977$ \\
\hline & Policy_effect & -0.004 & 0.043 & -0.09 & 0.928 & $\begin{array}{c}\sigma_{\mathrm{u}}=0.99, \sigma_{\mathrm{e}}=0.15 \\
\mathrm{~F}(155,304)=6.54^{\star * *}\end{array}$ \\
\hline \multirow{4}{*}{ Region 2} & Intercept & $20.33^{\star \star \star}$ & 0.124 & 163.33 & $<0.0001$ & R-square: within $=0.762$ \\
\hline & Treat & Omitted & & & & $\begin{array}{r}\text { between }=1.00 \\
\text { Corr }\left(\mathrm{u}_{\mathrm{i}} \mathrm{Xb}\right)=-0.048\end{array}$ \\
\hline & After & $0.868^{\star \star *}$ & 0.177 & 4.90 & $<0.0001$ & rho $=0.874$ \\
\hline & Policy_effect & -0.043 & 0.040 & -1.07 & 0.288 & $\begin{array}{c}\sigma_{\mathrm{u}}=0.46, \sigma_{\mathrm{e}}=0.18 \\
\mathrm{~F}(154,152)=3.17^{\star \star \star}\end{array}$ \\
\hline \multirow{4}{*}{ Region 3} & Intercept & $20.489^{* \star *}$ & 0.027 & 768.30 & $<0.0001$ & R-square: within $=0.969$ \\
\hline & Treat & Omitted & & & & $\begin{aligned} \text { between } & =0.028 \\
\text { Corr }(u, X b) & =0.005\end{aligned}$ \\
\hline & After & $0.671^{* \star *}$ & 0.038 & 17.77 & $<0.0001$ & rho $=0.980$ \\
\hline & Policy_effect & $0.042^{* \star *}$ & 0.0099 & 4.25 & $<0.0001$ & $\begin{array}{r}\sigma_{u}=0.38, \sigma_{e}=0.53 \\
F(154,458)=91.96^{\star \star \star}\end{array}$ \\
\hline \multirow{3}{*}{ Region 4} & $\begin{array}{c}\text { Intercept } \\
\text { Treat }\end{array}$ & $\begin{array}{l}19.89^{\star * \star} \\
\text { Omitted }\end{array}$ & 0.057 & 349.65 & $<0.0001$ & $\begin{array}{r}\text { R-square: } \text { within }=0.965 \\
\text { between }=1.00 \\
\operatorname{Corr}\left(u_{i}, X b\right)=-0.231\end{array}$ \\
\hline & After & $0.655^{\star \star \star}$ & 0.081 & 8.08 & $<0.0001$ & rho $=.983$ \\
\hline & Policy_effect & $-0.254^{\star \star *}$ & 0.018 & -13.74 & $<0.0001$ & $\begin{array}{r}\sigma_{u}=0.62, \sigma_{e}=0.80 \\
F(154,152)=27.65^{\star \star \star}\end{array}$ \\
\hline \multirow{4}{*}{ Region 5} & Intercept & $17.225^{\star \star *}$ & 0.083 & 208.04 & $<0.0001$ & R-square: within $=0.622$ \\
\hline & Treat & Omitted & & & & $\begin{array}{r}\text { between }=0.534 \\
\text { Corr }\left(\mathrm{u}_{\mathrm{i}}, \mathrm{Xb}\right)=-0.089\end{array}$ \\
\hline & After & 0.122 & .143 & 0.85 & 0.396 & rho $=0.997$ \\
\hline & Policy_effect & $0.078^{* *}$ & .031 & 2.51 & 0.012 & $\begin{array}{c}\sigma_{\mathrm{u}}=3.58, \sigma_{\mathrm{e}}=0.17 \\
\mathrm{~F}(154,454)=4.85^{\star \star \star}\end{array}$ \\
\hline
\end{tabular}

Notes: 1) Controlling for time variable of 154 weeks. 2) $\mathrm{N}=$ Sample size. 3) ${ }^{* * *},{ }^{* *}$ and, ${ }^{*}$ indicate statistical significance at the $1 \%, 5 \%$, and $10 \%$ levels, respectively (two-tailed t-test). 4) Omitted: Regression coefficient is not calculated due to collinearity. 
Table 7. Panel DID Results from EQ4 (Two Way Fixed Effects Model with Lagged Variable)

\begin{tabular}{|c|c|c|c|c|c|c|}
\hline & & Coefficient & SE & $\mathrm{t}$-value & $P>|t|$ & \\
\hline \multirow{5}{*}{ Whole } & Intercept & $19.83^{\star \star *}$ & 0.431 & 46.06 & $<0.0001$ & \multirow{5}{*}{$\begin{array}{r}\text { R-square: } \text { within }=0.715 \\
\text { between }=0.911 \\
\text { Corr }\left(u_{i}, X b\right)=-0.144 \\
\text { rho }=.996 \\
\sigma_{u}=2.35, \sigma_{e}=0.14 \\
F(156,2120)=34.12^{* * *}\end{array}$} \\
\hline & $\mathrm{Y}_{\mathrm{t}-1}$ & 0.015 & 0.022 & 0.66 & 0.507 & \\
\hline & Treat & 0.026 & 0.026 & 1.01 & 0.313 & \\
\hline & After & -0.034 & 0.024 & -1.41 & 0.158 & \\
\hline & Policy_effect & -0.011 & 0.012 & -0.92 & 0.356 & \\
\hline \multirow{5}{*}{ Region 1} & Intercept & $20.28^{\star \star *}$ & 0.125 & 162.47 & $<0.0001$ & \multirow{5}{*}{$\begin{array}{r}\text { R-square: } \text { within }=0.808 \\
\text { between }=0.999 \\
\text { Corr }\left(\mathrm{u}_{\mathrm{i}}, \mathrm{Xb}\right)=0.0006 \\
\text { rho }=.992 \\
\sigma_{\mathrm{u}}=1.50, \sigma_{\mathrm{e}}=0.14 \\
\mathrm{~F}(155,301)=8.18^{\star \star *}\end{array}$} \\
\hline & $Y_{t-1}$ & $-0.499^{\star \star *}$ & 0.054 & -9.28 & $<0.0001$ & \\
\hline & Treat & 0.014 & 0.029 & 0.46 & 0.645 & \\
\hline & After & $0.611^{\star * *}$ & 0.133 & 4.60 & $<0.0001$ & \\
\hline & Policy_effect & -0.009 & 0.038 & -0.23 & 0.819 & \\
\hline \multirow{5}{*}{ Region 2} & Intercept & $20.33^{\star * *}$ & 0.048 & 421.76 & 0.002 & \multirow{5}{*}{$\begin{array}{r}\text { R-square: within }=0.762 \\
\text { between }=1.00 \\
\text { Corr }\left(\mathrm{u}_{\mathrm{i}}, \mathrm{Xb}\right)=-0.048 \\
\text { rho }=.874 \\
\sigma_{\mathrm{u}}=0.66, \sigma_{\mathrm{e}}=0.80 \\
\mathrm{~F}(154,150)=3.54^{\star \star *}\end{array}$} \\
\hline & $\mathrm{Y}_{\mathrm{t}-1}$ & $-0.442^{\star \star *}$ & 0.086 & -5.15 & $<0.0001$ & \\
\hline & Treat & Omitted & & & & \\
\hline & After & -0.086 & 0.164 & -0.52 & 0.601 & \\
\hline & Policy_effect & $-0.0698^{*}$ & 0.308 & -1.85 & 0.066 & \\
\hline \multirow{5}{*}{ Region 3} & Intercept & $10.73^{\star \star \star}$ & 0.629 & 17.04 & $<.0001$ & \multirow{5}{*}{$\begin{aligned} & \text { R-square: } \text { within }=0.969 \\
& \text { between }=0.028 \\
& \operatorname{Corr}\left(\mathrm{u}_{\mathrm{i}}, \mathrm{Xb}\right)=0.556 \\
& \mathrm{rho}=0.966 \\
& \sigma_{\mathrm{u}}=0.19, \sigma_{\mathrm{e}}=0.04 \\
& \mathrm{~F}(154,454)=209.53^{*}\end{aligned}$} \\
\hline & $\mathrm{Y}_{\mathrm{t}-1}$ & $0.514^{* * *}$ & 0.031 & 17.72 & $<0.0001$ & \\
\hline & Treat & Omitted & & & & \\
\hline & After & $-0.676^{\star * \star}$ & 0.041 & -16.43 & $<0.0001$ & \\
\hline & Policy_effect & $0.018^{\star \star \star}$ & 0.006 & 2.70 & 0.007 & \\
\hline \multirow{5}{*}{ Region 4} & Intercept & $12.25^{\star \star \star}$ & 1.463 & 8.37 & $<0.0001$ & \multirow{5}{*}{$\begin{array}{r}\text { R-square: } \text { within }=0.971 \\
\text { between }=1.00 \\
\text { Corr }\left(u_{i}, X b\right)=0.350 \\
\text { rho }=.960 \\
\sigma_{u}=0.36, \sigma_{e}=0.07 \\
F(154,150)=32.54^{\star \star *}\end{array}$} \\
\hline & $\mathrm{Y}_{\mathrm{t}-1}$ & $0.416^{* * *}$ & 0.074 & 5.66 & $<0.0001$ & \\
\hline & Treat & Omitted & & & & \\
\hline & After & $0.350^{\star * *}$ & 0.106 & 3.31 & 0.001 & \\
\hline & Policy_effect & $-0.254^{\star \star *}$ & $5.22 \mathrm{e}-15$ & $-4.9 e+13$ & $<.0001$ & \\
\hline \multirow{5}{*}{ Region 5} & Intercept & $15.49^{\star \star *}$ & 0.788 & 19.64 & $<.0001$ & \multirow{5}{*}{$\begin{array}{r}\text { R-square: } \text { within }=0.638 \\
\text { between }=0.998 \\
\text { Corr }\left(u_{i}, X b\right)=0.88 \\
r h o=0.997 \\
\sigma_{u}=3.17, \sigma_{e}=0.16 \\
F(154,450)=5.16^{\star * *}\end{array}$} \\
\hline & $\mathrm{Y}_{\mathrm{t}-1}$ & $0.1167^{\star *}$ & 0.0455 & 2.56 & 0.011 & \\
\hline & Treat & Omitted & & & & \\
\hline & After & $-1.561^{\star \star *}$ & 0.139 & -11.18 & $<0.0001$ & \\
\hline & Policy_effect & $0.078^{* *}$ & 0.031 & 2.57 & 0.010 & \\
\hline
\end{tabular}

Note: ${ }^{* * *, * *}$ and, ${ }^{*}$ indicate statistical significance at the $1 \%, 5 \%$, and $10 \%$ levels, respectively (two-tailed t-test). 
impact of the regulation on sales. The positive impact in Region 3 might be related to the different treatment effects on the control group, where the closing days of the control group are the same as those of the treatment group. Under the condition that the closing days are the same for control and treatment groups, the negative impact of the regulation of business hours on sales is less for large discount stores of the treatment group than those of the control group. The significant negative impact of the regulation on sales in Region 4 comes from the typical discount stores of the treatment group that suffer from decreasing revenue due to the regulation of business hours.

\section{DISCUSSIONS AND POLICY IMPLICATIONS}

We tested the impact of Korea's Sunday superstore shopping regulation. The regulation was expected to reduce the revenue of the mega stores and SSMs due to the requirement of closing on two Sundays every month. However, our findings show the regulation can involve various types of effects on the revenue of the large discount stores including decreasing, increasing, and no significant impact.

First, the regulation of operation hours of large discount stores can directly involve a significant decreasing impact on their revenue because the regulation requires large discount stores to close two Sundays each month. In this case, the large discount stores may have made little effort to promote additional revenue through various types of marketing strategies.

Second, the regulation actually has little impact on the revenue despite the closing on two Sundays per month. Various reasons are related to this result. Above all, large discount stores are more likely to increase their sales during their business hours after the adoption of the regulation than before the regulation. The large discount stores are under a very competitive evaluation scheme. Each branch of the mega store faces a tight performance-based evaluation compared with their counterpart mega stores. This competitive environment may lead these mega stores to promote their revenues through various marketing strategies, which can compensate the reduction derived from the Sunday closing. After all, the impact of the regulation has no impact on the revenue.

Third, despite the regulation of the business hours, the revenue of some mega stores may increase due to external favorable business factors. For instance, despite the regulation of business hours, large discount stores of the treatment group could be located in a flourishing economic area that induces a significant increasing demand for retail sector. An increase of new consumers for mega stores can overcome the reduction part due to the closing hours and create more revenue. 
These findings illustrate that the regulation of business hours for mega stores can have various unintended effects on retail sector (Chun, 2015). Future regulation should consider these unexpected side effects, including destroying local markets, and delaying a new global retail ecosystem like buyer-driven commodity chains, to promote the competiveness of the retail sector. For instance, the large discount retail stores like Wal-Mart and Emart promote demand-responsive economies in East Asia, such as Taiwan and South Korea (Hamilton \& Gereffi, 2009). However, an inappropriate regulation against retail business and retail chains can prevent transforming from current distribution system to a new buyer-driven distribution system.

This research has several limitations to identifying the whole picture about how the regulation of business hours against the large discount retailers influences their distribution ecosystem and competitions among LDRs, SSMs, and traditional markets. We also use limited sales data from the sixteen mega stores in only five regions in South Korea. Further research is required to expand the scope of the impact of the regulation to include all of the mega stores in South Korea. In addition, our research focuses on the impact of the regulation on sales of the mega store chains. Further research is also necessary to examine a causal relationship of the sales or revenue between the mega stores and the local market stores. Research on the ecological changes of the retail sector before and after the regulation of business hours is similarly necessary to explore the whole picture of the impact of the regulation (Pickles et al. 2016). Regulation of entry and operating hours in retail sectors may involve various public policy issues (e.g., minimum wages and zoning regulation) that matter to the local market ecosystem, community life, and social capital. State intervention into retail sectors can also involve various economic and non-economic impacts on a new market ecosystem and strategic interactions between private(e.g., Emart, Lotte Mart) and public players (e.g., Central and local governments and public interest groups). 


\section{REFERENCES}

Basker, E. (2005a). Job creation or destruction? Labor market effects of Wal-Mart expansion. Review of Economics and Statistics, 87(1), 174-183.

Basker, E. (2005b). Selling a cheaper mousetrap: Wal-Mart's effect on retail prices. Journal of Urban Economics, 58(2), 203-229.

Bertrand, M., \& Kramarz, F. (2002). Does entry regulation hinder job creation? Evidence from the French retail industry. Quarterly Journal of Economics, 117(4), 1369-1413.

Bresnahan, T. F., \& Reiss, P. C. (1991). Entry and competition in concentrated markets. Journal of Political Economy, 99(5), 977-1009.

Cheshire, P., Hilber, C. A. L., \& Sanchis-Guarner, R. (2014). Do English Planning Policies Make Shopping More Sustainable. Unpublished. London School of Economics.

Cho, Y. S. (2014). Retailing and public policy: A comparative study of South Korea and foreign countries. Journal of Distribution Science, 12(7), 77-88.

Cho, J., Chun, H., \& Lee, Y. (2015). How does the entry of large discount stores increase retail employment? Evidence from Korea. Journal of Comparative Economics, 43(3), 559-574.

Cho, J., Chun, H., \& Lee, Y. (2014, March). Productivity Growth in the Retail Sector: Entry, Exit, and Reallocation. In EARIE Conference Paper.

Choi, Y. J., \& Jeong, J. (2016). Effects of the Sunday shopping restriction in Korea. Contemporary Economic Policy, 34(1), 203-215.

Chun, S. A. (2015). Good intentions, questionable results: a critical analysis of the shutdown of large retailers in South Korea. Australian Journal of Asian Law, 16(1) (Article 4), 1-20.

Ennis, S. (2010). Land Use Restrictions as Barriers to Entry. OECD Journal of Competition Law and Policy, 10(3), 7.

Foster, L., Haltiwanger, J., \& Krizan, C. J. (2006). Market selection, reallocation, and restructuring in the US retail trade sector in the 1990s. Review of Economics and Statistics, 88(4), 748-758.

Griffith, R., \& Harmgart, H. (2012). Supermarkets competition in England and planning regulation. The International Review of Retail, Distribution and Consumer Research, 22(1), 1-25.

Goos, M. (2005). Sinking the blues: The impact of shop closing hours on labor and product markets. Centre for Economic Performance, London School of Economics and Political Science.

Hamilton, G. G., \& Gereffi, G. (2009). Global commodity chains, market makers, and 
the rise of demand-responsive economies. Frontiers of Commodity Chain Research, 136-161.

Hausman, J., \& Leibtag, E. (2007). Consumer benefits from increased competition in shopping outlets: Measuring the effect of Wal-Mart. Journal of Applied Econometrics, 22(7), 1157-1177.

Jia, P. (2008). What happens when Wal-Mart comes to town: an empirical analysis of the discount retailing industry. Econometrica, 76(6), 1263-1316.

Jung, J., \& Kim, S. W. (2015). Systemic analysis of competition between SSM and small-to-medium retailers (SMR) in Korea. Indian Journal of Science and Technology, 8(19).

Kim, W., \& Hallsworth, A. G. (2013). Large format stores and the introduction of new regulatory controls in South Korea. The International Review of Retail, Distribution and Consumer Research, 23(2), 152-173.

Kim, B. (2016). The Welfare Effects of Sunday Shopping Regulation in Retail Markets (Doctoral dissertation, UNIVERSITY OF MINNESOTA).

Matsa, D. A. (2011). Competition and product quality in the supermarket industry. Quarterly Journal of Economics, 126(3): 1539-1591.

Pickles, J., Barrientos, S., \& Knorringa, P. (2016). New end markets, supermarket expansion and shifting social standards. Environment and Planning A, 48(7), 1284-1301.

Pilat, D. (1997). Regulation and Performance in the Distribution Sector. OECD Economics Department Working Paper, No. 180, OECD, Paris.

Sadun, R. (2015). Does planning regulation protect independent retailers?. Review of Economics and Statistics, 97(5), 983-1001.

Skuterud, M. (2005). The impact of Sunday shopping on employment and hours of work in the retail industry: Evidence from Canada. European Economic Review, 49(8), 1953-1978.

Wenzel, T. (2011). Deregulation of shopping hours: The impact on independent retailers and chain stores. The Scandinavian Journal of Economics, 113(1), 145-166.

Wrigley, N., \& Lowe, M. (2010). The globalization of trade in retail services. Organisation for Economic Co-operation and Development.

Williamson, B., Hargreaves, J., Bond, J., \& Lay, H. (2006). The Economic Costs and Benefits of Easing Sunday Shopping Restrictions on Large Stores in England and Wales. A report for the Department of Trade and Industry.

$<$ Media documents $>$

Yonhap News, "Supreme Court held the restriction of SSM business hours and mandatory closing not illegal", November 19, 2015. 
Appendix 1. Descriptive Statistics

\begin{tabular}{c|c|c|c|c|c}
\hline Variable & $\mathrm{N}$ & Mean & SD & Min & Max \\
\hline Lnsale & 2306 & 20.061 & 2.306 & 13.8 & 22.478 \\
\hline Sale & 2306 & $1,310,000,000$ & $969,000,000$ & $1,016,639$ & $5,780,000,000$ \\
\hline Treat & 2306 & 0.424 & 0.494 & 0 & 1 \\
\hline After & 2306 & 0.528 & 0.499 & 0 & 1 \\
\hline Policy_effect & 2306 & 0.235 & 0.424 & 0 & 1 \\
\hline Region & 2306 & 3.130 & 1.454 & 1 & 5 \\
\hline $\begin{array}{c}\text { Time } \\
\text { (Week) }\end{array}$ & 2306 & 77.368 & 44.390 & 1 & 154 \\
\hline
\end{tabular}

Appendix 2-1. Differences in Sales of SSM Before and After DIDA(Whole Group)

\begin{tabular}{|c|c|c|c|}
\hline & $\begin{array}{c}\text { Before } \\
\text { (Baseline Group) } \\
20.175(2.247) \\
(\mathrm{N}=1,089)\end{array}$ & $\begin{array}{c}\text { After } \\
\text { (Follow-up Group) } \\
19.959(2.354) \\
(\mathrm{N}=1,217)\end{array}$ & \\
\hline $\begin{array}{l}\text { Treatment Group(T) } \\
\qquad(\mathrm{N}=1,328)\end{array}$ & $\begin{array}{c}20.023(2.528) \\
\quad(N=653)\end{array}$ & $\begin{array}{c}19.984(2.564) \\
\quad(N=675)\end{array}$ & \\
\hline \multirow[t]{2}{*}{$\begin{array}{l}\text { Control Group }(C) \\
\qquad(N=978)\end{array}$} & $\begin{array}{l}20.277(2.034) \\
\quad(N=436)\end{array}$ & $\begin{array}{l}19.939(2.172) \\
\quad(N=542)\end{array}$ & \\
\hline & D1 & D2 & D2-D1 \\
\hline $\begin{array}{l}\text { Difference } \\
\quad(\mathrm{T}-\mathrm{C})\end{array}$ & $\begin{array}{r}-0.254(\mathrm{SE}=0.142) \\
\mathrm{t}-\text { value }=-1.79 \\
(\mathrm{p}>|\mathrm{t}|=0.074)\end{array}$ & $\begin{array}{r}0.045(S E=0.133) \\
t-\text { value }=0.34 \\
(p>|t|=0.735)\end{array}$ & $\begin{array}{r}0.299(\mathrm{SE}=0.195) \\
t-\mathrm{value}=1.54 \\
(p>|t|=0.125)\end{array}$ \\
\hline
\end{tabular}

Note: 1) $(\quad)=$ Standard deviation; $S E=$ Standard error. 2) Means and Standard Errors are estimated by linear regression. 3) Inference: $p<0.01$; ${ }^{* *} p<0.05 ;{ }^{*} p<0.1$. 
Appendix 2-2. Differences in Sales of SSM Before and After DIDA (Region 1: Three LDRs of Seoul Metropolitan )

\begin{tabular}{|c|c|c|c|}
\hline & $\begin{array}{l}\text { Before } \\
(\mathrm{N}=219)\end{array}$ & $\begin{array}{c}\text { After } \\
(\mathrm{N}=243)\end{array}$ & \\
\hline $\begin{array}{l}\text { Treatment Group(T) } \\
\qquad(\mathrm{N}=364)\end{array}$ & $\begin{array}{c}20.803 \\
(N=146)\end{array}$ & $\begin{array}{c}21.021 \\
(\mathrm{~N}=218)\end{array}$ & \\
\hline \multirow[t]{2}{*}{$\begin{array}{l}\text { Control Group }(C) \\
\qquad(N=98)\end{array}$} & $\begin{array}{l}21.865 \\
(N=73)\end{array}$ & $\begin{array}{l}21.894 \\
(N=25)\end{array}$ & \\
\hline & D1 & D2 & D2-D1 \\
\hline $\begin{array}{l}\text { Difference } \\
\quad(T-C)\end{array}$ & $\begin{array}{r}-1.062(\mathrm{SE}=0.109) \\
\mathrm{t}-\mathrm{value}=-9.74 \\
(\mathrm{p}>|\mathrm{t}|=<0.0001)\end{array}$ & $\begin{array}{r}-0.872(S E=0.161) \\
t-\text { value }=5.43 \\
(p>|t|=<0.0001)\end{array}$ & $\begin{array}{r}0.189(\mathrm{SE}=0.194) \\
\mathrm{t}-\text { value }=0.98 \\
(p>|t|=0.330)\end{array}$ \\
\hline
\end{tabular}

Note: 1) $\mathrm{SE}=$ Standard Error. 2) Means and Standard Errors are estimated by linear regression.

3) Inference: $p<0.01 ;{ }^{* *} p<0.05 ;{ }^{*} p<0.1$.

Appendix 2-3. Differences in Sales of SSM Before and After DIDA (Region 2: Two LDRs of Gyeonggi-Do)

\begin{tabular}{|c|c|c|c|}
\hline & $\begin{array}{c}\text { Before } \\
(N=154)\end{array}$ & $\begin{array}{c}\text { After } \\
(\mathrm{N}=154)\end{array}$ & \\
\hline $\begin{array}{l}\text { Treatment Group }(T) \\
\qquad(N=154)\end{array}$ & $\begin{array}{l}21.470 \\
(N=77)\end{array}$ & $\begin{array}{l}21.405 \\
(N=77)\end{array}$ & \\
\hline \multirow[t]{2}{*}{$\begin{array}{l}\text { Control Group }(C) \\
\qquad(N=154)\end{array}$} & $\begin{array}{l}20.814 \\
(N=77)\end{array}$ & $\begin{array}{l}20.792 \\
(N=77)\end{array}$ & \\
\hline & D1 & D2 & D2-D1 \\
\hline $\begin{array}{l}\text { Difference } \\
\quad(T-C)\end{array}$ & $\begin{array}{r}0.656(\mathrm{SE}=0.041) \\
t-\text { value }=16.00 \\
(p>|t|=<0.0001)\end{array}$ & $\begin{array}{r}0.613(\mathrm{SE}=0.041) \\
t-\text { value }=14.96 \\
(p>|t|=<0.0001)\end{array}$ & $\begin{array}{r}-0.043(\mathrm{SE}=0.058) \\
\mathrm{t}-\mathrm{value}=-0.74 \\
(\mathrm{p}>|\mathrm{t}|=0.461)\end{array}$ \\
\hline
\end{tabular}

Note: 1) $S E=$ Standard Error. 2) Means and Standard Errors are estimated by linear regression.

3) Inference: $p<0.01$; ${ }^{* *} p<0.05 ;{ }^{*} p<0.1$. 
Appendix 2-4. Differences in Sales of SSM Before and After DIDA (Region 3: Four LDRs of Gyeonggi-Do)

\begin{tabular}{|c|c|c|c|}
\hline & $\begin{array}{l}\text { Before } \\
(\mathrm{N}=312)\end{array}$ & $\begin{array}{c}\text { After } \\
(\mathrm{N}=304)\end{array}$ & \\
\hline $\begin{array}{l}\text { Treatment Group }(T) \\
\qquad(\mathrm{N}=154)\end{array}$ & $\begin{array}{l}21.238 \\
(N=78)\end{array}$ & $\begin{array}{l}21.219 \\
(N=76)\end{array}$ & \\
\hline \multirow[t]{2}{*}{$\begin{array}{l}\text { Control } \operatorname{Group}(\mathrm{C}) \\
\qquad(\mathrm{N}=462)\end{array}$} & $\begin{array}{c}21.131 \\
(\mathrm{~N}=234)\end{array}$ & $\begin{array}{c}21.071 \\
(N=228)\end{array}$ & \\
\hline & D1 & D2 & D2-D1 \\
\hline $\begin{array}{l}\text { Difference } \\
\qquad(T-C)\end{array}$ & $\begin{array}{r}0.106(S E=0.054) \\
t-\text { value }=1.96 \\
(p>|t|=0.051)\end{array}$ & $\begin{array}{r}0.148(S E=0.055) \\
t-\text { value }=2.70 \\
(p>|t|=0.007)\end{array}$ & $\begin{array}{r}0.042(\mathrm{SE}=0.077) \\
t-\text { value }=0.55 \\
(p>|t|=0.585)\end{array}$ \\
\hline
\end{tabular}

Note: 1) $S E=$ Standard Error. 2) Means and Standard Errors are estimated by linear regression.

3) Inference: $p<0.01 ;{ }^{* *} p<0.05 ;{ }^{*} p<0.1$.

Appendix 2-5. Differences in Sales of SSM Before and After DIDA (Region 4: Two LDRs of Gyeongsangbuk-Do)

\begin{tabular}{|c|c|c|c|}
\hline & $\begin{array}{l}\text { Before } \\
(N=136)\end{array}$ & $\begin{array}{c}\text { After } \\
(\mathrm{N}=172)\end{array}$ & \\
\hline $\begin{array}{l}\text { Treatment Group(T) } \\
\qquad(\mathrm{N}=154)\end{array}$ & $\begin{array}{l}21.001 \\
(N=68)\end{array}$ & $\begin{array}{l}20.691 \\
(N=86)\end{array}$ & \\
\hline \multirow[t]{2}{*}{$\begin{array}{l}\text { Control Group }(C) \\
\qquad(N=154)\end{array}$} & $\begin{array}{l}20.124 \\
(N=68)\end{array}$ & $\begin{array}{l}20.067 \\
(N=86)\end{array}$ & \\
\hline & D1 & D2 & D2-D1 \\
\hline $\begin{array}{l}\text { Difference } \\
\qquad(\mathrm{T}-\mathrm{C})\end{array}$ & $\begin{array}{r}0.877(\mathrm{SE}=0.049) \\
t-\text { value }=17.92 \\
(p>|t|=>0.0001)\end{array}$ & $\begin{array}{r}0.623(\mathrm{SE}=0.044) \\
\mathrm{t}-\mathrm{value}=14.33 \\
(p>|t|=>0.0001)\end{array}$ & $\begin{array}{r}-0.254(\mathrm{SE}=0.065) \\
\mathrm{t}-\mathrm{value}=-3.87 \\
(p>|t|=>0.0001)\end{array}$ \\
\hline
\end{tabular}

Note: 1) $S E=$ Standard Error. 2) Means and Standard Errors are estimated by linear regression.

3) Inference: $p<0.01 ;{ }^{* *} p<0.05 ;{ }^{*} p<0.1$. 
Appendix 2-6. Differences in Sales of SSM Before and After DIDA (Region 5: Four LDRs of Ulsan)

\begin{tabular}{|c|c|c|c|}
\hline & $\begin{array}{l}\text { Before } \\
(\mathrm{N}=268)\end{array}$ & $\begin{array}{c}\text { After } \\
(\mathrm{N}=344)\end{array}$ & \\
\hline $\begin{array}{l}\text { Treatment Group }(T) \\
\qquad(\mathrm{N}=152)\end{array}$ & $\begin{array}{l}14.250 \\
(N=67)\end{array}$ & $\begin{array}{l}14.216 \\
(N=85)\end{array}$ & \\
\hline \multirow[t]{2}{*}{$\begin{array}{l}\text { Control } \operatorname{Group}(C) \\
\qquad(\mathrm{N}=460)\end{array}$} & $\begin{array}{c}18.551 \\
(N=201)\end{array}$ & $\begin{array}{c}18.458 \\
(N=259)\end{array}$ & \\
\hline & D1 & D2 & D2-D1 \\
\hline $\begin{array}{l}\text { Difference } \\
\qquad(T-C)\end{array}$ & $\begin{array}{r}-4.301(\mathrm{SE}=0.351) \\
\mathrm{t}-\mathrm{value}=-12.25 \\
(\mathrm{p}>|\mathrm{t}|=<0.0001)\end{array}$ & $\begin{array}{r}-4.242(\mathrm{SE}=0.311) \\
t-\text { value }=-13.63 \\
(p>|t|=<0.0001)\end{array}$ & $\begin{array}{r}-0.059(S E=0.469) \\
t-v a l u e=0.13 \\
(p>|t|=0.899)\end{array}$ \\
\hline
\end{tabular}

Note: 1) $S E=$ Standard Error. 2) Means and Standard Errors are estimated by linear regression.

3) Inference: $p<0.01 ;{ }^{* *} p<0.05 ;{ }^{*} p<0.1$. 